\title{
Faktor Penghambat dalam Mengatasi Ketidakhadiran Siswa Kelas XI IPS di SMAN 1 Lubuk Basung
}

\author{
Alfatah Reski Basevi Putra ${ }^{1}$, Desri Nora $A N^{2}$ \\ ${ }^{1,2}$ Universitas Negeri Padang \\ Email: alfatahreski@gmail.com, desrinora@ymail.com
}

\begin{abstract}
Abstrak
Artikel ini dilatarbelakangi oleh fenomena tingginya ketidakhadiran siswa pada jam pelajaran di SMAN 1 Lubuk Basung. Adapun penyebab ketidakhadiran siswa tersebut karena ada keperluan (izin), sakit dan tanpa keterangan (alfa). Pihak sekolah sudah menerapkan aturan wajib kehadiran $80 \%$ dan sanksi bagi siswa yang kehadirannya kurang dari $80 \%$, untuk mengantisipasi hal ini, namun sekolah mengalami kendala dalam meminimalkan ketidakhadiran siswa (alfa) agar dapat terus mengikuti proses pembelajaran. Tujuan dari penelitian ini ialah mengetahui faktor penghambat dalam mengatasi ketidakhadiran siswa kelas XI IPS di SMAN 1 Lubuk Basung. Penelitian ini menggunakan pendekatan Kualitatif dengan tipe Studi Kasus. Penelitian menggunakan teori dari Talcott Parson yaitu teori Struktural Fungsional dengan skema AGIL. Teknik pemilihan informan adalah purposive sampling, dengan jumlah informan 32 orang. Adapun yang menghambat dalam usaha mengatasi ketidakhadiran siswa alfa disebabkan oleh faktor: (a) Penerapan Sanksi Yang Kurang Tegas, (b) Kurangnya Kerjasama Antara Personil Sekolah, (c) Jadwal Sekolah Yang Kurang Efektif, (d) Kurangnya Minat Siswa Dalam Mengikuti Proses Pembelajaran, (e) Fasilitas Sekolah Pasca Kebakaran.
\end{abstract}

Kata kunci: Disiplin, Sanksi, Ketidakhadiran Siswa, Sekolah

\section{Abstract}

This article is motivated by the phenomenon of the absence of students during class hours at SMAN 1 Lubuk Basung. Because the cause of the student's absence is because there is a need (permission), illness and without notice (alpha). $80 \%$ and penalties for students who take less than $80 \%$, to approve this, but the school must discuss the absence of students (alpha) in order to continue the learning process. The purpose of this study is to study the inhibiting factors in overcoming the absence of class XI IPS students at SMAN 1 Lubuk Basung. This study uses a qualitative case study type. The research uses theory from Talcott Parson, namely Structural Theory with AGIL certification. The informant selection technique is purposive sampling, with 32 informants. Regarding the obstacles in the effort to overcome the absence of alpha students caused by factors: (a) Application of Less Firm Sanctions, (b) Lack of Cooperation Between School Personnel, (c) Less Effective School Schedules, (d) Lack of Student Interest in Checking Processes Learning, (e) Post Fire School Facilities.

Keywords: Discipline, Punishment, Absence of Students, School

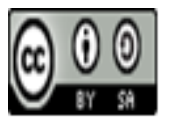

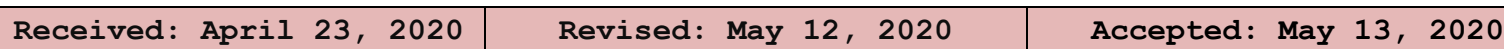




\section{Pendahuluan}

Pendidikan merupakan salah satu faktor penting bagi terwujudnya suatu kehidupan yang dinamis bagi suatu bangsa sekaligus terbangunnya suatu peradaban bangsa (Fitria, 2018). berdasarkan Undang-undang Republik Indonesia no 20 tahun 2003 tentang sistem pendidikan nasional, pendidikan ialah suatu usaha sadar dan terencana untuk mewujudkan suasana belajar dan proses pembelajaran agar peserta didik secara aktif mengembangkan potensi dirinya untuk memiliki kekuatan spiritual keagamaan, pengendalian diri, kepribadian, kecerdasan, akhlak mulia, serta keterampilan yang diperlukan dirinya, masyarakat, bangsa dan negara (Elisa \& Wrastari, 2013). Sekolah merupakan salah satu lembaga pendidikan tempat belajar dimana anak akan berusaha untuk dibina, mengembangkan dan menyempurnakan potensi dirinya serta dunia kehidupan dan masa depannya. Sekolah merupakan salah satu tempat mempersiapkan generasi muda menjadi manusia yang dewasa dan berbudaya (Djahiri, 2006). Sekolah merupakan lembaga pendidikan formal yang didalamnya terdapat aktifitas guru dalam mengajar, mendidik, membimbing, dan melatih serta memperbaiki perilaku siswa (Arsaf, 2016). Sekolah juga merupakan tempat setiap anak mendapatkan pendidikan baik ilmu pengetahuan maupun pendidikan nilai-nilai moral serta pembentukan karakter setiap peserta didik. Sekolah yang merupakan lembaga pendidikan, mempunyai fungsi dan tugas edukatif yang meliputi tiga dimensi yaitu mendidik yang menghasilkan etika dalam pergaulan, mengajar menghasilkan kecerdasan dan melatih menghasilkan keterampilan. Secara garis besar fungsi sekolah adalah mendidik calon warganegara yang dewasa, mempersiapkan calon warga masyarakat, mengembangkan cita-cita profesi atau kerja, mempersiapkan calon pembentuk keluarga yang baru, pengembangan pribadi (Atmodiwiryo, 2000). Artinya bahwa sekolah merupakan salah satu lembaga pendidikan formal yang berupaya membina, mengembangkan, dan menyempurnakan segenap potensi yang ada pada diri anak menuju proses pendewasaan.

Sekolah sebagai lembaga pendidikan memiliki tanggung jawab yang besar terhadap keberhasilan belajar peserta didik. Keberhasilan belajar bukan hanya ditandai dengan penguasaan materi belaka, melainkan lebih dari itu diharapkan terwujudnya manusia yang memiliki kemampuan untuk mengembangkan keterampilan dan sikap disiplin. Untuk menanamkan sikap disiplin, sekolah membuat peraturan atau tata tertib tentang persyaratan minimal kehadiran siswa untuk mengikuti pelajaran di sekolah. Hal ini telah dinyatakan dalam Lampiran Permendiknas no 19 Tahun 2007 point 5 tentang bidang kurikulum dan kegiatan pembelajaran butir e mengenai peraturan akademik, yang berisi, (1) Sekolah/Madrasah menyusun dan menetapkan peraturan akademik, (2) Peraturan akademik berisi: persyaratan minimal kehadiran siswa untuk mengikuti pelajaran dan tugas dari guru, ketentuan mengenai ulangan, remedial, ujian,kenaikan kelas, dan kelulusan, ketentuan mengenai hak siswa untuk menggunakan fasilitas belajar, laboratorium, perpustakaan, penggunaan buku pelajaran, buku referensi, dan buku perpustakaan, ketentuan mengenai layanan konsultasi kepada guru mata pelajaran, wali kelas, dan konselor. (3) peraturan akademik diputuskan oleh staf dewan pendidik dan ditetapkan oleh kepala sekolah (Permendiknas, 2007).

Pada umumnya salah satu masalah yang sering terjadi di sekolah adalah ketidakhadiran siswa. Penyebab siswa tidak hadir ke sekolah dapat dikategorikan menjadi 3 bagian, yaitu : (1) alfa yaitu ketidakhadiran tanpa keterangan yang jelas dengan alasan yang tidak bisa dipertanggungjawabkan (2) izin yaitu ketidakhadiran dengan keterangan dan alasan tertentu yang bisa dipertanggungjawabkan, biasanya disertai surat pemberitahuan dari orang tua; dan (3) sakit yaitu ketidakhadiran dengan alasan gangguan kesehatan, biasanya disertai surat pemberitahuan dari orang tua atau surat keterangan sakit dari dokter (Gustina, 2014). Berdasarkan dengan lampiran Permendiknas no 19 Tahun 2007 tentang bidang kurikulum dan kegiatan pembelajaran butir e mengenai peraturan akademik yang berisi tentang persyaratan minimal kehadiran siswa untuk mengikuti pelajaran, SMAN 1 Lubuk Basung telah membuat peraturan mengenai tingkat kehadiran yang dimana siswa wajib mengikuti pembelajaran tatap muka minimal $80 \%$ dari jumlah

Jurnal Sikola: Jurnal Kajian Pendidikan dan Pembelajaran Vol. 1, No. 4, Th. 2020 
total tatap muka efektif dalam satu tahun pelajaran. Berikut peraturan tata tertib sekolah SMAN 1 Lubuk Basung: (1) Peserta didik hadir 10 menit sebelum bel masuk berbunyi, bel masuk dibunyikan jam 07.25 WIB. Proses PBM aktif jam 07.30 wib dan pagar ditutup jam 07.35 (kecuali senin bel masuk jam 07.15 wib untuk pelaksanaan upacara), (2) Peserta didik yang masuk terlambat maksimal 10 menit (sampai jam 07.40 ) dapat arahan/ sanksi dari piket pembina diizinkan masuk kelas setelah dapat surat izin masuk dari guru piket, (3) Peserta didik yang terlambat lebih dari 10 menit mendapat arahan/sanksi dari piket pembina disuruh ke Bimbingan Konseling untuk pembinaan dan dapat masuk kelas pada jam pelajaran ke 2 setelah dapat surat izin dari guru Bimbingan Konseling, (4) Peserta didik yang terlambat sampai jam 08.00 wib atau lebih dengan alasan yang jelas harus mendapatkan surat izin masuk dari Pimpinan Sekolah, (5) Peserta didik yang sakit lebih dari 3 hari, agar mengirimkan kesekolah surat keterangan sakit dari dokter, (6) Peserta didik yang sakit dalam jam pelajaran atau ada halangan penting diizinkan meninggalkan sekolah setelah mendapatkan izin dari guru mata pelajaran dan guru piket, (7) Peserta didik yang kehadirannya kurang dari $80 \%$ tidak diperbolehkan mengikuti ujian semester/ akhir kecuali sakit yang dilengkapi dengan surat keterangan dari dokter, (8) Kehadiran piket pembina pada hari yang ditentukan : 1 orang digerbang depan dibantu satpam dan guru piket, 1 orang guru piket di meja piket.

Berdasarkan peraturan yang telah ditetapkan oleh SMAN 1 Lubuk Basung, yaitu tingkat kehadiran siswa harus mencapai $80 \%$, dan apabila kehadiran dibawah $80 \%$ dan siswa yang melanggar dengan tingkat kehadirannya kurang dari yang telah ditetapkan, maka sekolah akan memberikan buat sanksi : (1) Peserta didik yang tidak hadir tanpa kabar 3 hari berturut-turut dipanggil orang tua, (2) Peserta didik yang berada di luar lingkungan sekolah dan terjaring SATPOL PP dipanggil orang tua dan diskor 1 minggu, (3) Peserta didik yang merusak sarana/prasarana sekolah diganti oleh peserta didik yang bersangkutan, (4) Sarana/ prasarana yang ada di kelas bila dirusak oleh peserta didik diganti oleh kelas, (5) Peserta didik yang terlibat kriminal, amoral/asusila, narkoba, mencemarkan nama sekolah dikembalikan kepada orang tua.

Penjelasan diatas dapat menjelaskan bahwa siswa yang tidak hadir 3 kali berturut-turut maka akan dipanggil orang tuanya. Dalam sanksi tersebut kehadiran yang terkait itu pada absen dengan keterangan alfa karena tidak memiliki keterangan yang jelas mengapa siswa tersebut tidak hadir ke sekolah. Berikut ini data awal kehadiran siswa kelas XI IPS SMAN 1 Lubuk Basung yang peneliti peroleh dari guru bimbingan konseling dan wali kelas.

Tabel 1. Rekap Ketidakhadiran Siswa Semester Ganjil dan Semester Genap Kelas XI IPS SMAN 1 Lubuk Basung Tahun Ajaran 2018/2019

\begin{tabular}{c|c|c|c|c|c|c|c|c|c}
\hline No & Kelas & $\begin{array}{c}\text { Jumlah } \\
\text { Siswa } \\
\text { Semester I }\end{array}$ & \multicolumn{2}{|c|}{$\begin{array}{c}\text { Jumlah } \\
\text { Ketidakhadiran }\end{array}$} & $\begin{array}{c}\text { Jumlah } \\
\text { Siswa } \\
\text { Semester II }\end{array}$ & \multicolumn{3}{|c}{$\begin{array}{c}\text { Jumlah } \\
\text { Ketidakhadiran }\end{array}$} \\
\hline & & & Sakit & Izin & Alfa & & Sakit & Izin & Alfa \\
\hline 1 & XI IPS 1 & 31 & 48 & 25 & 25 & 31 & 30 & 26 & 26 \\
\hline 2 & XI IPS 2 & 31 & 18 & 81 & 31 & 31 & 12 & 50 & 32 \\
\hline 3 & XI IPS 3 & 31 & 90 & 38 & 85 & 31 & 80 & 35 & 79 \\
\hline 4 & XI IPS 4 & 29 & 80 & 60 & 19 & 29 & 80 & 43 & 25 \\
\hline 5 & XI IPS 5 & 32 & 52 & 64 & 41 & 32 & 55 & 60 & 44 \\
\hline
\end{tabular}

Sumber: Buku absensi siswa XI IPS SMAN 1 Lubuk Basung

Dari tabel diatas dapat dilihat ketidakhadiran siswa-siswi SMAN 1 Lubuk Basung pada semester I dan Semester II tahun pelajaran 2018-2019, mengalami penurunan jumlah 
ketidakhadiran siswa pada semester 2 baik itu alfa, izin, dan sakit. Akan tetapi jumlah ketidakhadiran siswa kelas XI IPS tetap besar. Berdasarkan peraturan yang tertulis didalam peraturan tata tertib mengenai kehadiran siswa, yaitu siswa yang tingkat kehadirannya kurang dari $80 \%$ tidak boleh mengikuti ujian semester/ akhir, kecuali sakit dan izin yang dilengkapi dengan keterangan dari dokter maupun institusi terkait. Maka dari itu berikut tabel yang menunjukkan persentase tingkat ketidakhadiran siswa yang kurang dari $80 \%$.

Tabel 2. Persentase Ketidakhadiran Siswa XI IPS SMAN 1 Lubuk Basung kurang dari 80\%

\begin{tabular}{cccc}
\hline No & Semester & Jumlah Siswa & $\begin{array}{c}\text { Persentase Ketidakhadiran } \\
\text { dibawah } \mathbf{8 0} \%\end{array}$ \\
\hline 1 & Ganjil & 154 & $19 \%$ \\
\hline 2 & Genap & 154 & $20 \%$ \\
\hline
\end{tabular}

Sumber: Rekap absensi dokumentasi guru bimbingan konseling

Dari tabel diatas menunjukkan bahwa tingkat kehadiran yang diharapkan oleh sekolah sebesar $80 \%$ tidak terpenuhi, pada tabel tersebut menunjukkan tingkat kehadiran persentase pada keterangan alfa. Berdasarkan data diatas menarik bagi peneliti untuk meneliti kendala sekolah dalam mengatasi ketidakhadiran siswa kelas XI IPS di SMAN 1 Lubuk Basung. Fokus permasalahan dalam penelitian ini adalah melihat faktor penghambat dalam mengatasi ketidakhadiran siswa kelas XI IPS di SMAN 1 Lubuk Basung. Peneliti meneliti ketidakhadiran siswa pada keterangan alfa, karena keterangan alfa itu tidak dapat diterima pertanggung jawabnya. Faktor penghambat dalam meminimalkan ketidakhadiran siswa ini dianalisis menggunakan teori Struktural Fungsional oleh Talcott Parson dengan skema AGIL.

\section{Metode Penelitian}

Penelitian ini menggunakan pendekatan kualitatif (Nuryanto, 2017), pendekatan kualitatif bermaksud untuk memahami fenomena tentang apa yang dialami oleh subjek penelitian secara holistik, dan dengan cara deskripsi dalam bentuk kata-kata dan bahasa, pada suatu konteks khusus yang alamiah dan dengan memanfaatkan berbagai metode ilmiah. Tipe penelitian adalah studi kasus. Studi kasus merupakan tipe penelitian yang dapat mengungkapkan gambaran yang mendalam dan mendetail tentang suatu situasi atau objek (Yusuf, 2007). Teknik pemilihan informan menggunakan purposive sampling dengan informan berjumlah 32 orang, yang terdiri dari kepala sekolah, wakil kepala sekolah, guru BK, guru mata pelajaran, wali kelas, dan siswa kelas XI IPS. Penelitian ini penelitian lakukan pada semester Januari-Juni 2020 di SMAN 1 Lubuk Basung, dalam pengambilan data peneliti melakukan wawancara secara terstruktur, observasi dan dokumen. Peneliti melakukan wawancara kepada informan untuk mengetahui informasi mengenai kendala sekolah dalam mengatasi ketidakhadiran siswa kelas XI IPS di SMAN 1 Lubuk Basung. Dalam wawancara, peneliti memberikan pertanyaan secara tertulis dan disampaikan secara lisan kepada informan, kemudian peneliti mencatat keterangan atau jawaban dari informan, dalam mewawancarai peneliti dibantu juga dengan alat perekam suara (Lestariningsih, 2017). Studi dokumentasi merupakan pelengkap dari penggunaan metode observasi dan wawancara dalam penelitian (Nilamsari, 2014). Studi dokumentasi pengumpulan data yang menghasilkan catatan-catatan penting yang berhubungan dengan masalah yang diteliti, sehingga akan diperoleh data yang lengkap, sah bukan berdasarkan perkiraan (Basrowi \& Suwandi, 2008). Dokumen yang diperlukan dalam penelitian berupa data peraturan tata tertib sekolah, rekapitulasi absen siswa, pelanggaran siswa terhadap tata tertib sekolah, dan dokumen lainnya yang berhubungan dengan topik yang akan diteliti. Agar data yang diperoleh lebih valid, maka penelitian ini dilakukan triangulasi. Teknik ini dilakukan dengan mengajukan pertanyaan yang

Jurnal Sikola: Jurnal Kajian Pendidikan dan Pembelajaran Vol. 1, No. 4, Th. 2020 
sama kepada informan yang berbeda dengan tujuan mendapatkan data yang sama. Analisis data dilakukan dengan tiga jalur kegiatan yang terjadi secara bersama, yaitu reduksi data, penyajian data, dan penarikkan kesimpulan (Nugroho, 2019).

\section{Hasil dan Pembahasan}

Kendala memiliki arti halangan, rintangan, faktor atau keadaan yang membatasi, menghalangi, atau mencegah pencapaian sasaran, kekuatan yang memaksa pembatalan pelaksanaan. Sekolah merupakan tempat pendidikan lanjutan setelah lingkungan keluarga. Sekolah sebagai lembaga pendidikan mempunyai tanggung jawab besar untuk mencapai tujuan pendidikan. Di sekolah juga mengembangkan aturan yang berlaku untuk mengatur kedudukan dan peranan seseorang sesuai dengan tujuan yang hendak dicapai. Sekolah juga bertugas membentuk kepribadian yang luhur, mulia, serta berdisiplin yang tinggi. Penelitian menemukan data kendala/hambatan yang dihadapi sekolah, yang meliputi faktor atau keadaan yang membatasi, menghambat segala usaha yang telah dilakukan oleh sekolah dalam upaya pelaksanaan mengatasi ketidakhadiran siswa di SMAN 1 Lubuk Basung. Mengatasi adalah segala sesuatu usaha yang dilakukan untuk menyelesaikan masalah atau apapun hal lain. Mengatasi merupakan suatu cara untuk menyelesaikan atau memperbaiki sesuatu hal yang akan mengakibatkan permasalahan. Kehadiran di sekolah bukan hanya berarti siswa secara fisik ada di sekolah, melainkan yang lebih penting ialah keterlibatan siswa dalam kegiatan-kegiatan disekolah (Yusuf, 2007). Berdasarkan penjelasan di atas yang dimaksud dengan mengatasi ketidakhadiran siswa dalam penelitian ini adalah suatu cara atau usaha yang dilakukan sekolah untuk menyelesaikan dan memperbaiki ketiadaan partisipasi secara fisik siswa terhadap kegiatankegiatan yang ada di sekolah.

Adapun faktor penghambat dalam mengatasi ketidakhadiran siswa dengan status alfa di kelas XI SMAN 1 Lubuk Basung yaitu (a) Penerapan Sanksi Yang Kurang Tegas, (b) Kurangnya Kerjasama Antara Personil Sekolah, (c) Jadwal Sekolah Yang Kurang Efektif, (d) Kurangnya Minat Siswa Dalam Mengikuti Proses Pembelajaran, (d) Fasilitas Sekolah Pasca Kebakaran.

\section{Penerapan Sanksi yang Kurang Tegas}

Sekolah sebagai lembaga pendidikan memiliki tanggung jawab yang besar terhadap keberhasilan belajar siswa. Keberhasilan belajar siswa bukan hanya ditandai dengan penguasaan materi belajar saja, melainkan lebih dari itu diharapkan terwujudnya manusia yang memiliki kemampuan untuk mengembangkan keterampilan dan sikap. Maka dari itu diperlukan suatu peraturan dan tata tertib. Sekolah merupakan suatu sistem yang terdiri dari setiap struktur didalam sistem sosial, fungsional terhadap yang lain. Sebaliknya kalau tidak fungsinoal maka struktur tidak akan ada atau hilang (Aulawi, 2016). Salah satu dari sistem itu tata tertib diperlukan untuk menciptakan suasana sekolah yang aman, nyaman, dan tertib sehingga terhindar dari peristiwaperistiwa negative serta meningkatkan prestasi belajar siswa dalam hal kehadiran dan ketidakhadiran siswa (Yudiawan, 2019). Tata tertib sekolah adalah ketentuan-ketentuan yang mengatur kehidupan sekolah sehari-hari dan mengandung sanksi (hukuman) bagi yang melanggar. Sanksi dibuat tanpa pandang bulu, dan tanpa diskriminasi, semua orang akian mendapatkan sesuai dengan bentuk pelanggaran yang telah diperbuatnya. Tidak ada memandang fisik, suku, agama, RAS tertentu, baik itu kaya maupun miskin, semuanya akan mendapatkan hukuman yang setimpal sesuai dengan peraturan apa yang dilanggar.

Sanksi dapat berbentuk lisan maupun tulisan, hukuman yang bersifat mendidik tanpa adanya kekerasan. Hukuman secara lisan seperti teguran dari guru, dan tulisan memberi surat peringatan yang dimana orang tua siswa dipanggil dan datang ke sekolah. Dan melakukan skorsing bila melakukan pelanggaran yang sama secara berulang-ulang serta mengeluarkan siswa yang bermasalah dari sekolah atau diberi pilihan pindah ke sekolah lain. Dalam halnya mengatasi ketidakhadiran siswa, sekolah telah berupaya agar siswa tidak sering absen ke sekolah, seperti

Jurnal Sikola: Jurnal Kajian Pendidikan dan Pembelajaran Vol. 1, No. 4, Th. 2020 
siswa yang telah absen 3 kali akan dipanggil oleh guru BK yang memegang kelas dimana siswa tersebut. Guru BK lalu memberikan bimbingan individu lalu siswa tersebut diminta membuat dan mentandatangani surat perjanjian agar tidak mengulangi perbuatan yang sama lagi, surat tersebut ditulis langsung ke dalam surat yang sudah di sediakan oleh guru dan ditandatangani oleh siswa, guru bimbingan konseling, dan wali kelas. Seorang guru bimbingan konseling harus mampu mengetahui kecakapan metode pendekatan yang harus digunakan untuk mengatasi masalah siswanya (Istikomah, 2016). Berbagai upaya dan tindakan telah dilakukan oleh sekolah akan tetapi peringatan dan sanksi yang diberikan tidak membuat siswa merasa jera dan mengulangi kesalahan yang sama.

\section{Kurangnya Kerjasama Antar Personil Sekolah}

Sekolah merupakan institusi formal berupa lingkungan fisik dengan berbagai perlengkapan yang merupakan tempat yang tepat bagi siswa dalam tahap perkembangannya dan merupakan salah satu lingkungan sosial yang berpengaruh terhadap kehidupan mereka. Akan tetapi, kenyataan yang sering ditemukan disekolah adalah masih banyak siswa yang melanggar tata tertib atau peraturan sekolah (Ulani, Salim, \& Imran, 2018). Menurut Talcott Parson dalam teorinya Struktural Fungsional menyatakan bahwa masyarakat adalah suatu sistem yang terdiri dari bagian-bagian yang saling berhubungan dan fungsional antara satu bagian dengan bagian yang lain. Apabila ada satu bagian yang tidak berfungsi dengan baik, maka akan mempengaruhi seluruh bagian yang ada dalam sistem itu. Sekolah merupakan sebuah sistem yang didalamnya terdiri dari bagian-bagian, seperti kepala sekolah, wakil kepala sekolah, guru-guru, pegawai sekolah, satpam, dan lain-lain. Semua bagian ini harus menjalankan fungsinya dengan baik, agar keseimbangan sekolah tetap terjaga. Dalam sistem di sekolah setiap komponen atau sub sistem memiliki fungsi bagi komponen yang lainnya seperti disekolah dalam mengatur ketidakhadiran siswa setiap komponen memilki fungsi yang berbeda namun tujuan yang sama yakni agar tujuan sekolah tercapai salah satunya dibidang absensi siswa. Seperti yang telah dijelaskan bahwa fungsi dari masing-masing sub sistem sekolah harus saling berkesinambungan. Akan tetapi kurangnya kerja sama personil sekolah terhadap pemberlakuan peraturan mengenai absensi siswa yang kurang dari ketentuan. Kepala sekolah yang hanya memberi penyuluhan mengenai pentingnya kehadiran siswa, pada saat pelaksanaannya yang seharusnya menjadi tanggung jawab bersama mengenai masalah ini, seakan melimpahkan masalah kehadiran ini kepada guru bimbingan konseling, menyerahkan sepenuhnya kepada satu pihak dan itu membuat kurangnya kerjasama antar personil sekolah. Pada saat terjadi masalah pada siswa, wali kelas melimpahkan masalah ketidakhadiran ini ke guru bimbingan konseling sepenuhnya. Seharusnya harus ada kerjasama antara wali kelas dengan guru bimbingan konseling, bukan hanya melimpahkan ke satu pihak saja. Dalam peraturan yang apabila absensi siswa kurang dari $80 \%$ kehadiran, maka tidak diperkenankan untuk mengikuti ujian dan tidak akan naik kelas. Tetapi pada kenyataannya siswa tersebut tetap bisa mengikuti ujian dan bahkan naik kelas. Kurangnya komunikasi dan kerjasama antar pesonil membuat peraturan yang telah dibuat, tidak terlaksana sesuai dengan ketentuan yang ada. Sehingga tidak membuat efek jera bagi siswa, mereka beranggapan tata tertib yang dibuat hanya sekedar peraturan yang tertulis tanpa penerapan yang kurang tegas dari sekolah.

\section{Jadwal Masuk Sekolah Yang Kurang Efektif}

Setiap sekolah memiliki jadwal masuk sekolah yang beragam, apalagi beberapa sekolah di Indonesia sudah menerapkan fulldays school. Dengan jadwal masuk 06.45-15.30 WIB, Berbeda dengan halnya jadwal masuk SMAN 1 Lubuk Basung, sekolah memberlakukan jadwal masuk pukul 07.15-14.20 WIB, dan memulai pembelajaran pada pukul 07.30 WIB, dalam rentang waktu sekitar 15 menit digunakan untuk Literasi. Pada jadwal yang diterapkan oleh SMAN 1 Lubuk Basung dapat dilihat jadwal masuk yang diberlakukan kurang efektif, sedangkan sekolah lain memberlakukan jadwal masuk itu pukul $07.00 \mathrm{WIB}$, itupun dengan maksimal keterlambatan 10 
menit, jadi proses belajar mengajar dilakukan pada pukul 07.10 WIB. dari jadwal masuk yang diterapkan SMAN 1 Lubuk Basung membuat siswa terbiasa bangun kesiangan dan siswa seperti terbiasa terlambat datang kesekolah. Sedangkan dengan jadwal yang telah memberi keringanan terhadap siswa, masih saja siswa itu datang terlambat dan terkadang mereka bahkan lebih memilih untuk cabut pada saat datang kesekolah dan mereka tahu bahwa mereka sudah terlambat, mereka lebih memilih pergi ke warung untuk merokok dan jajan dari pada masuk karena sudah terlambat, mereka beralasan bahwa malu untuk masuk dan mereka sudah beberapa kali terlambat dan takut diberi hukuman dipanggil orang tuannya, maka dari itu mereka lebih memilih untuk tidak hadir sama sekali dan membuat surat sakit palsu yang ditulis sendiri dan meminta teman untuk memberikan ke guru, karena bakal dihitung dalam absensi dengan keterangan alfa maupun sakit. Jadwal masuk merupakan bagian dari tata tertib hal ini merupakan proses adaptasi yaitu sebuah sistem harus menyesuaikan dengan kebutuhan yang dibutuhkan. Namun jadwal masuk sekolah yang kurang efektif membuat siswa banyak yang tidak hadir dengan berbagai faktor, hal ini disebut goal attainment (pencapaian tujuan) bahwa suatu sistem harus mendefinisikan dan mencapaim tujuan utamanya.

Adanya kendala yang ditemui sekolah dalam menegakkan kedisiplinan dengan jadwal masuk sekolah yang kurang efektif, oleh sebab itu sekolah memiliki upaya dalam meminimalisir kendala yang ada, hal ini disebut integration (integrasi) agar sistem tetap mencapai kestabilan sistem maka perlunya menjaga komitmen dari berbagai pihak demi mencapai tujuan tersebut. Hal ini disebut latency (pemeliharaan pola-pola) proses belajar mengajar sebagai sistem memiliki subsub bagian yang setiap sub bagian fungsional bagi yang lainnya.

\section{Kurangnya Minat Siswa dalam Mengikuti Proses Pembelajaran}

Proses belajar mengajar merupakan inti dari proses pendidikan secara keseluruhan dengan guru sebagai pemegang peranan utama. Pembelajaran merupakan aspek yang komplek dan melibatkan berbagai hal yang saling berkaitan. Oleh karena itu untuk menciptakan pembelajaran yang kreatif dan menyenangkan diperlukan berbagai keterampilan (Syarifuddin, 2011). Proses belajar mengajar merupakan suatu proses yang mengandung serangkaian perbuatan guru dan siswa atas dasar hubungan timbal balik yang berlangsung dalam situasi edukatif untuk mencapai tujuan tertentu. Untuk mencapai tujuan pembelajaran maka dibutuhkan penggunaan metode pembelajaran yang bervariasi yang dapat menunjang kegiatan belajar mengajar, karena salah satu faktor yang membuat siswa kurang aktif di dalam pelajaran dikarenakan metode yang digunakan kurang variatif dan terkesan monoton. Pada saat peneliti di lokasi melihat bahwa guru-guru yang mengajar hanya menggunakan metode ceramah, disamping menggunakan proyektor, walaupun menggunakan proyektor, dalam menjelaskan materi pembelajaran guru masih memberikan dan menjelaskan materi dengan menggunakan metode ceramah.

Tujuan kegiatan belajar mengajar tidak akan pernah tercapai jika pemilihan dan komponen yang terdapat dalam proses belajar mengajar tidak dilakukan dngan baik terutama dalam penggunaan metode pembelajaran. Dengan metode pembelajaran yang bervariatif dapat menunjang kegiatan belajar mengajar dan berpengaruh terhadap minat siswa untuk mengikuti kegiatan belajar mengajar di kelas bahkan berpengaruh terhadap minat siswa untuk hadir ke sekolah. Sering siswa kurang berminat terhadap pelajaran karena metode yang digunakan itu-itu saja, hal ini dapat dilihat dari sikap siswa dalam menerima pelajaran, ada yang siswa berbicara dengan teman sebelahnya pada saat guru sedang menyampaikan pelajaran, keluar masuk kelas, bahkan ada siswa yang bosan untuk kesekolah karena kegiatan pembelajaran yang membosankan. Hal ini disebabkan metode pembelajaran yang digunakan guru masih kurang tepat. Hal tersebut terlihat di sekolah tempat dilakukannya penelitian, karena metode yang digunakan kurang bervariasi.

Siswa merupakan bagian dari sub sistem yang memiliki fungsi yang sangat penting bagi sekolah. Dalam proses belajar mengajar siswa berperan sebagai objek dan subjek (Abbas \&

Jurnal Sikola: Jurnal Kajian Pendidikan dan Pembelajaran Vol. 1, No. 4, Th. 2020 
Hidayat, 2018). Minat siswa yang kurang dalam mengikuti pembelajaran menyebabkan tujuan sekolah tentunya tidak tercapai merupakan proses adaptasi yaitu sebuah sistem harus menyesuaikan dengan kebutuhan yang dibutuhkan. Namun siswa yang memiliki kurang minat dalam mengikuti pembelajaran membuat siswa banyak yang tidak hadir kesekolah yang dikarenakan metode yang digunakan kurang bervariasi yang menjadikan siswa malas belajar sehingga tidak datang ke sekolah, hal ini disebut goal attainment (pencapaian tujuan) bahwa suatu sistem harus mendefinisikan dan mencapai tujuan utamanya.

Adanya faktor penghambat yang ditemui sekolah dalam menegakkan kedisiplinan siswa dalam mengikuti pelajaran, oleh sebab itu guru memiliki upaya dalam meminimalisir faktor yang ada, guru sebagai pendidik, pengajar, pembimbing dan evaluator (Maghfiroh, 2016), hal ini disebut integration (integrasi) yaitu sebuah sistem harus mengatur hubungan bagian-bagian yang menjadi komponennya. Agar sistem tetap stabil maka perlunya komitmen dari berbagai pihak demi tercapainya tujuan tersebut. Hal ini disebut latency (pemeliharaan pola-pola). Proses belajar mengajar sebagai sistem memiliki sub-sub bagian yang setiap bagian sub sistem fungsional bagi sistem lainnya.

\section{Keadaan Fasilitas Sekolah Pasca Kebakaran}

Fasilitas sekolah sangat penting bagi keberlangsungan proses belajar mengajar. Fasilitas sekolah yang mencukupi membuat proses proses pelaksanaan belajar di sekolah akan dicapai dngan baik. Fasilitas sekolah seperti tersedianya ruangan yang menunjang kenyamanan bagi siswa maupun warga sekolah untuk tetap berada di lingkungan sekolah. Sebaliknya fasilitas sekolah yang terbatas dapat membuat siswa tidak betah berada di lingkungan sekolah dan keluar masuk pekarangan sekolah sebelum waktu pulang sekolah bahkan memotivasi siswa untuk melakukan pelanggaran seperti bolos pada jam sekolah. Untuk meningkatkan prestasi dan kehadiran siswa, sekolah perlu menyempurnakan kurikulum, melengkapi sarana dan prasaranadan sebagainya (Mulyani, 2017).

Peneliti melihat bahwa ada beberapa ruangan yang berada di sekolah itu hangus akibat kebakaran beberapa bulan sebelum peneliti PLK disana. Ruangan yang mengalami kebakaran antara lain: ruang BK, ruang UKS, beberapa ruang kelas, ruang koperasi, dan ruang OSIS. Untuk beberapa kelas yang terbakar, sekolah menggunakan ruang labor kimia yang berada di luar lingkungan sekolah. Kelas yang berada diluar yakni kelas x ips 1 dan x ipa 2. Dan untuk ruangan pengganti lainnya belum tersedia dikarenakan sekolah tidak memiliki ruangan yang cukup. Untuk ruangan bimbingan konseling, sekolah menggunakan sementara ruang piket sebagai ruangan sementara. Di ruangan piket tersebut yang sekarang dipakai sebagai ruanganbimbingan konseling, diruangan piket itulah guru bimbingan konseling melakukan kegiatannya, membimbing dan membina siswa-siswi yang dipanggil dan bermasalah, sehingga dalam melakukan pembinaan kepada siswa tidak terlaksana dengan maksimal, dikarenakan ruangan tersebut masih digunakan sebagai ruang piket. Penjelasan diatas dapat menjelaskan kendala yang dihadapi oleh sekolah dalam mengatasi ketidakhadiran siswa kelas xi ips di SMAN 1 Lubuk Basung. Diharapkan dengan hasil temuan tersebut maka pihak sekolah dapat segera meperbaiki dan mengevaluasi kekurangankekurangan yang ada demi membuat sekolah dapat berjalan dengan lebih baik

Sekolah merupakan sebuah sistem yang didalamnya terdiri dari sub-sub sistem, yang terdiri dari kepala sekolah, wakil kepala sekolah, guru-guru, pegawai sekolah, satpam dan lain-lain. Semua bagian sitem ini harus menjalankan fungsinya dengan baik, agar keseimbangan sekolah tetap terjaga. Namun dalam penelitian ini jelas terlihat bahwa sekolah mengalami gangguan yang disebabkan oleh sub sistemnya yaitu fasilitas sekolah. Fasilitas merupakan faktor panunjang bagi keberhasilan suatu sistem sekolah sehingga menjadi bagian dari sub sistem yang memiliki fungsi yang sangat penting bagi sekolah. Ketersedianya fasilitas merupakan proses adaption (adaptasi) yaitu sebuah sistem harus menyesuaikan dengan kebutuhan yang dibutuhkan. Namun fasilitas sekolah tidak lengkap karena kebakaran yang terjadi dan membuat siswa untuk tidak hadir, hal 
ini disebut goal attainment (pencapaian tujuan) bahwa suatu sistem harus mendefinisikan dan mencapai tujuan utamanya.

Adanya faktor penghambat yang ditemui sekolah dalam menegakkan kedisiplinan dengan mengupayakan kelas yang ada, oleh sebab itu guru memiliki upaya untuk meminimalisir keadaan yang ada, hal ini disebut integration (integrasi) sebuah sistem harus mengatur hubungan bagian yang menjadi komponennya. Hal ini disebut latency (pemeliharaan pola-pola). Proses belajar mengajar sebagai sistem memiliki sub-sub bagian yang setiap sub sistem fungsional bagi sistem lainnya.

\section{Struktural Fungsional}

Untuk menganalisis mengenai kendala sekolah dalam mengatasi ketidakhadiran siswa kelas XI IPS di SMAN 1 Lubuk Basung, peneliti menggunakan teori struktural fungsional oleh Talcott parson (Ambo, 2010). Struktural fungsional menekankan pada keteraturan, memandang masyarakat sebagai suatu sistem sosial (Maunah, 2015). Struktural fungsional mengatakan bahwa masyarakat merupakan suatu sistem yang terdiri dari bagian-bagian yang saling berhubungan dan fungsional antara satu bagian dengan bagian lain. Apabila satu bagian yang tidak berfungsi dengan baik, maka akan mempengaruhi bagian dari sistem tersebut. Teori struktural fungsional menjelaskan bagaimana berfungsinya suatu struktur. Setiap struktur (mikro seperti persahabatan, meso seperti organisasi, dan makro seperti masyarakat dalam arti luas seperti masyarakat jawa) akan tetap ada sepanjang ia memiliki fungsi (Damsar, 2011). Asumsi dasar dari teori ini adalah bahwa setiap struktur dalam sistem sosial, fungsional terhadap yang lain. Sebaliknya kalau tidak fungsional maka struktur tidak akan ada atau tidak saling berkesinambungan. Menurut teori Fungsionalis ini masyarakat adalah suatu sistem yang terdiri dari bagian-bagian atau elemen yang saling berkaitan dan saling menyatu dalam keseimbangan. Perubahan yang terjadi pada satu bagian akan membawa perubahan pula pada bagian-bagian yang lain (Ritzer, 2003). Perubahan satu akan membawa perubahan pula terhadap bagian lain. Asumsi dasarnya adalah bahwa setiap struktur dalam sistem sosial, fungsional terhadap sistem lain. Teori struktural fungsional parson yang dinamakan dengan skema AGIL yang memuat empat fungsi yang diperlukan untuk semua sistem "tindakan" yaitu adaptation, goal attainment, integration, latency (Maunah, 2015). Skema AGIL Parson, yakni adaptation (adaptasi): sistem harus mengatasi, dan menyesuaikan lingkungan dengan kebutuhannya, goal attainment (pencapaian tujuan): sistem harus mendefinisikan dan mencapai tujuan utamanya, integration (integrasi): sistem harus mengatur hubungan bagian-bagian yang menjadi komponennya, latency (latensi/pemeliharaan pola-pola): sistem harus melengkapi, memelihara, memperbaharui motivasi individu dan pola-pola budaya menciptakan dan mempertahankan pola (Purnomo, 2014).

Sekolah merupakan suatu sistem yang terdiri dari berbagai sub-sub sistem yang terstruktur dan memiliki fungsi yang saling berhubungan dan berkeseimbangan. Sekolah adalah salah satu institusi formal yang menjadi agen internalisasi nilai dan membentuk karakter peserta didiknya. Dalam penelitian ini peneliti menemukan faktor penghambat sekolah dalam meminimalkan ketidakhadiran siswa dan belum optimalnya sekolah mewujudkan aturan disiplin sehingga siswa mampu dibentuk taat kesepakatan bersama dan takut akan sanksi. Peningkatan partisipasi pendidikan belum sepenuhnya diikuti oleh pendidikan karakter dan karakter luhur yang mampu membangun karakter nasional yang kuat. Pendidikan karakter memiliki peran penting dalam upaya pembangunan karakter dalam arti luas yang melibatkan kementerian / lembaga, komunitas, sekolah, dan orang tua yang relevan untuk mendukung perwujudan peradaban bangsa yang unggul dan mulia. (Mulyaningsih, Nuryana, Sylvia, Casmudi, \& Haluti, 2019).

Didalam penelitian ini peneliti memakai teori struktural fungsional dengan skema AGIL. Keterkaitan skema AGIL dengan penelitian ini yakni tata tertib menyangkut dengan kedisiplinan siswa tentang ketidakhadiran siswa, hal ini merupakan proses adaptasi yang dimana sistem harus 
menyesuaikan dengan kebutuhan yang dibutuhkan. Namun sanksi yang telah diterapkan sekolah tidak tegas sehingga siswa masih sering terjadi pelanggaran seperti absensi siswa yang bermasalah, hal ini disebut goal attainment (pencapaian tujuan) bahwa suatu sistem harus mendefinisikan dan mencapai tujuan utamanya yakni agar siswa tetap mematuhi tata tertib dan sanksi yang ada. Adanya kendala yang ditemui sekoah dalam menegakkan kedisiplinan dengan adanya sanksi tidak berjalan semestinya, oleh karena itu sekolah berupaya untuk meminimalisir kesalahan yang ada, ini sebut integrasi yang dimana sistem harus mengatur hubungan bagian-bagian yang menjadi komponennya. Agar sistem tetap stabil maka perlunya komitmen dari berbagai pihak yang ada didalam sekolah untuk mencapai tujuan, hal ini disebut latensi (pemeliharan pola-pola). Oleh karena itu perlu adanya terobosan dalam mencapai pemecahannya sehingga tujuan pendidikan dapat tercapai dan sesuai dengan yang diharapkan (Sya'bany, 2017). Proses belajar mengajar sebagai sistem memiliki sub-sub bagian yang setiap sub sistem fungsional bagi sistem lainnya. itulah keterkaitan sruktural fungsional dengan skema AGIL terhadap penelitian ini.

Jika untuk hadir di sekolah saja siswa masih mengalami kendala dan sekolah juga memiliki hambatan untuk dapat dengan tegas meningkatkan kehadiran siswa, maka sikap disiplin siswa yang perlu mendapatkan perhatian. Sekolah sebagai sebuah sistem dan komponen-komponen yang terlibat dalam sistem ini harus bersama-sama berupaya untuk (1) Mengarahkan energi untuk belajar secara kontinu, (2) Melakukan perencanaan dan implementasi agar tercipta proses belajar dengan sungguh-sungguh dan tidak membiarkan terbuang, (3) Mengupayakan siswa untuk patuh terhadap aturan yang diberikan guru di dalam kelas, (4) Mengupayakan siswa patuh dan taat terhadap tata tertib belajar di sekolah, (5) Mengupayakan program agar siswa dapat menunjukkan sikap antusias dalam belajar, (6) Mengupayakan pengembangan program agar siswa mampu mengikuti kegiatan pembelajaran di kelas dengan gairah dan partisipatif, (7) Mengupayakan siswa agar menyelesaikan tugas-tugas yang diberikan guru dengan baik, (8) Mengupayakan siswa agar tidak melakukan hal-hal yang dilarang oleh guru. (Septiani \& Sylvia, 2019), karena kualitas pelaksanaan pembelajaran di sekolah adalah pondasi awal keberhasilan proses pendidikan, namun saat ini penilaian sumatif sering menjadi acuan orang tua dan guru dalam melihat kompetensi yang telah diperoleh peserta didik.(Sylvia, Anwar, \& Khairani, 2019).

\section{Kesimpulan}

Pada tahun ajaran 2018/2019 kehadiran siswa kelas XI IPS tidak mencapai target yang telah dibuat oleh SMAN 1 Lubuk Basung sebesar 80\%. Berikut kendala yang dihadapi oleh SMAN 1 Lubuk Basung dalam mengatasi ketidakhadiran siswa, Pertama penerapan sanksi yang kurang tegas. Penerapan sanksi yang dilakukan sekolah hanya pada tahap pembinaan dan pemanggilan orang tua. Sedangkan menurut peraturan yang dibuat oleh sekolah mengatakan bahwa bagi siswa yang absen kurang dari $80 \%$ tidak perbolehkan ikut ujian dan tidak naik kelas, namun dalam penerapan siswa yang tingkat kehadirannya yang kurang dari $80 \%$ tetap saja naik kelas. Kedua kurangnya kerjasama antara personil sekolah. Kerjasama antara personil sekolah yaitu guru bidang studi, guru bimbingan konseling, wali kelas siswa dan wakil kepala kesiswaan dalam mengatasi ketidakhadiran siswa sangat diperlukan. Ketiga jadwal sekolah yang kurang efektif. SMAN 1 Lubuk Basung memiliki jadwal masuk pada pukul 07.15 yang ini dirasakan kurang efektif, dikarenakan jadwal sekolah pada umumnya itu pukul 06.45 WIB dengan keterlambatan 10 menit. Keempat kurangnya minat siswa dalam mengikuti proses belajar mengajar karena metode yang digunakan kurang variatif. Kelima Fasilitas sekolah pasca kebakaran. Fasilitas sekolah pasca sekolah membuat beberapa bangunan berkurang dan menyebabkan aktifitas dan kegiatan sekolah terganggu dikarenakan bangunan sekolah yang tidak mencukupi. Pada tahun ajaran 2020 nanti diharapkan tingkat kehadiran siswa kelas XI IPS lebih baik, bukan hanya kelas XI IPS saja akan tetapi semua siswa-siswi SMAN 1 Lubuk Basung dapat meningkatkan absensi mereka sehingga tercapai 80\% kehadiran sesuai dengan yang diharapkan oleh sekolah. 
Alfatah Reski Basevi Putra, Desri Nora AN Faktor Penghambat dalam Mengatasi Ketidakhadiran Siswa Kelas XI IPS di SMAN 1 Lubuk Basung

\section{Daftar Pustaka}

Abbas, \& Hidayat, M. Y. (2018). Faktor-Faktor Kesulitan Belajar Fisika Pada Peserta Didik. Jurnal Pendidikan Fisika, 6(1), 45-49.

Ambo, U. (2010). Tradisi Aliran dalam Sosiologi dari Filosofi Positivistik ke Post Positivistik (2010 ed.). Jakarta: Rajawali Perss.

Arsaf, N. A. (2016). Faktor Penyebab Pelanggaran Tata Tertib (Studi Pada Siswa di SMA Negeri 18 Makassar). Jurnal Sosialisasi Pendidikan-FIS UNM, 2(1), 33-41.

Atmodiwiryo, S. (2000). Manajemen Pendidikan Indonesia. Jakarta: Ardadizya Jaya.

Aulawi, M. (2016). Bab II Struktural Fungsional Talcott Parson. digilib UINSBY.

Basrowi, B \& Suwandi, S. (2008). Memahami Penelitian Kualitatif. Jakarta: Rineka Cipta.

Damsar. (2011). Pengantar Sosiologi Pendidikan. Jakarta: Kencana Prenada Media Group.

Djahiri, K. (2006). Pendidikan Nilai Moral dalam Dimensi Pendidikan Kewarganegaraan. Bandung: Lab PKN UPI Bandung.

Elisa, S., \& Wrastari, A. T. (2013). Sikap Guru Terhadap Pendidikan Inklusi Ditinjau dari Faktor Pembentuk Sikap [Teachers' attitudes toward inclusive education viewed from the forming factors of attitude]. Jurnal Psikologi Perkembangan dan Pendidikan, 2(1), 1-10.

Fitria, R. N. (2018). Penerapan Karakter Kedisiplinan Siswa di MI Darusalam Wonodadi Blitar. Journal of Chemical Information and Modeling, 53(9), 1689-1699. https://doi.org/10.1017/ CBO9781107415324.004

Gustina, R. (2014). Tingkat Kehadiran Siswa Dalam Proses Pembelajaran Dan Usaha Guru Pembimbing Dalam Meningkatkannya di Sekolah Menengah Atas Negeri 2 Kampar. Repositori. UIN Suska.

Istikomah, N. (2016). Peran Guru Bimbingan Konseling Dalam Mengatasi Masalah Kedisiplinan Siswa di SMP Muhammadiyah 05 Wonosegoro Kabupaten Boyolali. Disertasi. IAIN Salatiga

Lestariningsih, D. (2017). Implementasi Pendidikan Karakter Nilai Disiplin dan Tanggung Jawab dalam Mata Pelajaran Penjasorkes pada Kelas IV di SD N Suryodiningratan I Yogyakarta . Dwi Lestariningsih Universitas PGRI Yogyakart. Jurnal Universitas PGRI Yogyakarta, 2(1), 110 .

Maghfiroh, F. T. (2016). Upaya Guru Kelas Dalam Pembentukan Kecamatan Belik Kabupaten Pemalang. Jurnal Pendidikan Guru Madrasah Ibtidaiyah, 6(1), 23-44.

Maunah, B. (2015). Pendidikan Dalam Perspektif Struktural Fungsional. Cendekia: Journal of Education and Teaching, 9(1), 71. https://doi.org/10.30957/cendekia.v9i1.53

Mulyani, A. (2017). Jurnal Konseling dan Pendidikan Peningkatan Kehadiran Siswa kelas XI Pemasaran 2 Menggunakan Konseling Perorangan Teknik Eklektik. Jurnal Konseling dan Pendidikan, 5(3), 167-171.

Mulyaningsih, I., Nuryana, Z., Sylvia, I., Casmudi, C., \& Haluti, F. (2019). Addressing the Blockages of Education and Culture Development. Test Engineering and Management, 81(1102), 1102-1106.

Nilamsari, N. (2014). Memahami Studi Dokumen Dalam Penelitian Kualitatif. Jurnal Wacana, 14(2), 177-181.

Nugroho, W. (2019). Pengaruh Layanan Mediasi Terhadap Perilaku Bullying. Jurnal Medi Kons vol. 5 No. 2 Oktober 2019, 5(2), 103-114.

Nuryanto, S. (2017). Manajemen Kegiatan Ekstrakurikuler di SD A1 Irsyad 01 Purwokerto. Jurnal Kependidikan, 5(1), 151-168. https://doi.org/10.24090/jk.v5i1.1260

Permendiknas. (2007). Standar Pengelolaan Pendidikan (Permendiknas). Bandung: Citra Umbara.

Purnomo, S. (2014). Krisis Karakter Dalam Perspektif Teori Struktural Fungsional. Jurnal Pembangunan Pendidikan: Fondasi dan Aplikasi, 2(1), 72-81.

Ritzer, G. (2003). Sosiologi Ilmu Pengetahuan Berparadigma Ganda. Jakarta: PT Raja Grafindo

Jurnal Sikola: Jurnal Kajian Pendidikan dan Pembelajaran Vol. 1, No. 4, Th. 2020 
Persada.

Septiani, H., \& Sylvia, I. (2019). Hubungan Intensitas Penggunaan Smartphone dengan Disiplin Belajar Siswa Kelas X SMA 2 Pariaman. Jurnal Sikola: Jurnal Kajian Pendidikan dan Pembelajaran, 1(1), 80-90. https://doi.org/10.24036/sikola.v1i1.12

Sya'bany, N. I. (2017). Analisis Faktor Penghambat Kemampuan Berbicara Bahasa Arab (khiwar) Siswa Kelas XI SMA Islam AL Badriyah Rarang Lombok Timur. Jurnal Universitas Islam Negeri Mataram, 6(1), 5-9.

Syarifuddin, A. (2011). Penerapan Model Pembelajaran Cooperative Belajar Dan Faktor-Faktor Yang Mempengaruhinya. Ta'dib, 16(01), 113-136.

Sylvia, I., Anwar, S., \& Khairani, K. (2019). Pengembangan Instrumen Penilaian Autentik Berbasis Pendekatan Authentic Inquiry Learning Pada Mata Pelajaran Sosiologi di Sekolah Menengah Atas. Jurnal Socius: Journal of Sociology Research and Education, 6(2), 103-120. https://doi.org/10.24036/scs.v6i2.162

Ulani, D., Salim, I., \& Imran. (2018). Penerapan Tata Tertib Sekolah Dalam Mengatasi Pelanggaran Siswa di MTS Negeri Sungai Pinyuh. Jurnal Pendidikan dan Pembelajaran Khatulistiwa, 7(1), 1-13.

Yudiawan, A. (2019). Analisis Korelasi Tingkat Absensi dengan Hasil Belajar Siswa MTs . Sains al-Gebra Kota Sorong Papua Barat. Jurnal STAIN Sorong, 11(9), 353-373.

Yusuf, A.M. (2007). Metodologi Penelitian Dasar-Dasar Penyelidikan Ilmiah. Padang: UNP Press. 